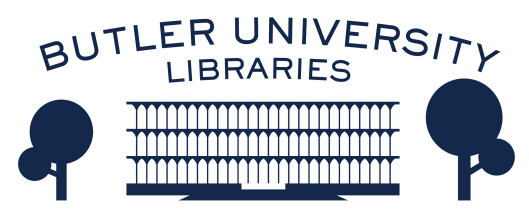

Journal of Hindu-Christian Studies

Volume 9

Article 8

January 1996

\title{
Saved by the Word: The Christian Understanding of the Relationship Between Scripture and Salvation
}

Michael DeRoche

Follow this and additional works at: https://digitalcommons.butler.edu/jhcs

Part of the Religion Commons

\section{Recommended Citation}

DeRoche, Michael (1996) "Saved by the Word: The Christian Understanding of the Relationship Between Scripture and Salvation," Journal of Hindu-Christian Studies: Vol. 9, Article 8.

Available at: https://doi.org/10.7825/2164-6279.1130

The Journal of Hindu-Christian Studies is a publication of the Society for Hindu-Christian Studies. The digital version is made available by Digital Commons @ Butler University. For questions about the Journal or the Society, please contact cbauman@butler.edu. For more information about Digital Commons @ Butler University, please contact digitalscholarship@butler.edu. 


\title{
Saved by the Word: The Christian Understanding of the Relationship Between Scripture and Salvation
}

\author{
Michael DeRoche \\ Department of Religious Studies \\ Memorial University of Newfoundland
}

SCRIPTURE AND SALVATION - from a Christian point of view, both are gifts from God. Yet they are not of equal import. For Christianity salvation is fundamental: it is the goal of life, indeed it is life eternal. Scripture, on the other hand, is instrumental: it leads one to salvation. As the Christian scriptures themselves put it: "... the sacred writings.. are able to instruct you for salvation through faith in Christ Jesus" (2 $\operatorname{Tim}$ 3:15b).

For Christianity "salvation" is the term that describes the spiritual needs of human beings. According to Christianity, the human condition is characterized by sin. This sinful condition not only separates human beings from God, it prevents any union between them. As God is the source of life and represents the ultimate good, this situation represents a considerable problem. Those who exist in a state of sinfulness are thought to be without contact with the true source of being. An individual in this condition is considered to fall short of the true potential of human existence. They are often described as being in the dark or being lost. Traditionally Christianity considers such a condition to be evil and the sinner to be under the influence of the forces of evil. For Paul sin constitutes spiritual death (Rom 6:16-17), and those who die in a state of sinfulness are traditionally believed to spend eternity suffering the torment of hell.

Salvation constitutes the solution to the problem of sin. The experience of salvation is believed to remove the individual from the state or influence of sin and to place the devotee firmly on the side of God. Salvation implies the commitment of the individual to God and the divine cause. No longer is the individual concerned with themselves, but with God. In some this commitment is so strong that the devotee loses all sense of their own individuality. Their individual identity is overwhelmed by the divine presence they feel within themselves. Such is the experience of salvation that Christians speak of it as a new birth. Upon experiencing salvation, Christians traditionally understand themselves as having acquired eternal life which they believe will be spent in heaven in the presence of God. This state is commonly understood as one of ultimate bliss and represents for Christians the ultimate good.

Human beings, however, are unable to acquire salvation by themselves. According to Augustine, their sinful condition renders any effort on their part null and void. They have neither the strength, nor the integrity, nor the intelligence to negate the sin that prevents them from entering God's presence and eternal life. Left to themselves, humans are incapable of experiencing salvation. Fortunately, God provides for human salvation, and He does so, Christianity maintains, through the person of Jesus Christ. Although the debate amongst 
theologians over the processes by which Christ accomplishes salvation on behalf of humanity seems endless, the faith nonetheless agrees that he is essential to its availability. ${ }^{1}$ It is Christ who negates the sin that has proven such a monkey on the back of humanity. It is Christ who provides eternal life. As Paul puts it, "For the wages of $\sin$ is death, but the free gift of God is eternal life in Christ Jesus our Lord" (Rom 6:23).

In Christianity scripture is adjuvant to salvation. Its role, as the above citation from 2 Tim 3:15b indicates, is pedagogical: it instructs about salvation with the hope of leading its reader to salvation. It accomplishes this aim in a variety of ways. First, it informs its readers about the person of Jesus Christ. Importantly, what it provides is not a biography of the man but, as Mark 1:1 puts it, "the gospel of Jesus Christ, the Son of God".

The word "gospel" means "good news". While the term has come to refer to the written accounts of the life and teachings of Jesus, originally it referred to the content of the Christian message about Jesus. Christians preached the "gospel" long before it existed in a written form. ${ }^{2}$ Thus while the written gospels may resemble biography, ${ }^{3}$ their interest is not in the details of Jesus's life, but in the significance or "good news" of that life. That is why so many of the details that would be of interest to the historian are not provided. The gospels are interested only in those details that demonstrate the soteriological meaning of the life and death of God's own Son. As John 21:25 indicates, the author knows more details about Jesus's life than he includes in his gospel. Being interested in salvation, he only includes those that contribute to his message. As he explains in 20:31 “ ... these are written that you may believe that Jesus is the Christ, the Son of God, and that believing you may have life in his name".

From the perspective of the canonical gospels, ${ }^{4}$ the climax of the life of Jesus is the events surrounding his death and resurrection. It is these events, Christianity believes, that make salvation possible. Through his death on the cross, Paul maintains, Christ atones for the sin that inhibits humanity from becoming "God-like" (Rom 3:23-25; 4:25). By his resurrection Christ provides humanity with the means to achieve eternal life and enter the Kingdom of God. As Paul wrote to the Christians in Rome,

For if we have been united with him in
a death like his, we shall certainly be
united with him in a resurrection like
his. We know that our old self was
crucified with him so that the sinful
body might be destroyed. ... But if we
have died with Christ, we believe that
we shall also live with him. (Rom 6:5-
8)

All that is required of anyone wanting to claim God's gift of salvation is faith in the truth of these claims. ${ }^{5}$

Of course, not everything in the Christian Bible appears to be about Jesus Christ. Only its second part, the New Testament, clearly has Christ as its subject. The Old Testament, a collection of sacred Jewish texts older than, yet accepted as scripture by Christianity, recounts events that happened long before Jesus lived. Yet Christianity has always maintained that these writings are in one way or another about Christ and God's desire to offer humanity salvation. While the links between the two Testaments have not always been obvious, and Christianity had to develop a variety of methods to "discover" Christ in the Old Testament, ${ }^{6}$ the Old Testament has generally been understood as anticipating the New, and the acts recounted therein as prefiguring or prophesying the soteriological aspects of the life of Christ.

From a Christian perspective the Old Testament's most important prophetic role concerns the figure of the messiah. The Old Testament contains a number of predictions that God will send a messiah or similar figure to save his people from their plight. "Messiah" means the anointed one. 
Originally it was a political term used for the kings of the ancient kingdoms of Israel and Judah, and later for the kings and then high priests of the second-century-B.C.E. Hellenistic temple state of Judah. By extension it came to refer to the hope of the Jewish people that God would one day restore a divinely led community of righteous believers. This spiritualized messiah would have direct knowledge of God's will which would give him special divine powers, including the abilities to keep God's enemies at bay, an acute sense of justice, and the power to restore health, even human life. ${ }^{7}$

For Christians, of course, Jesus is the Messiah. Indeed, "christ" is the Greek word for "messiah". Although the Old Testament does not mention Jesus by name, Christianity traditionally interprets these predictions as a reference to him because in its view he fulfils all messianic expectations. ${ }^{8}$ As son of David (Matt 1:1) and a member of the order of Melchizedek (Heb 5:6), Jesus is the "king" and "priest" who is assigned by God to lead the community of saints in worship. Jesus can heal the sick, feed the hungry, and make the lame walk. But most importantly, according to Christianity, Jesus Christ resurrected and in so doing defeated the greatest enemy of all, death. As Jesus claims in the gospel of John, "I am the bread of life; he who comes to me shall not hunger, and he who believes in me shall never thirst" (John 6:35). To put it another way, Jesus is the messianic saviour offering eternal life to all who join his body (double entendre intended) of believers.

The Old Testament is also understood as a history of God's earlier efforts at offering salvation to humanity. The Genesis story of the expulsion of Adam and Eve, the first human couple, from the garden of Eden accounts for the need for salvation. By disobeying God's command not to eat from the tree of the knowledge of good and evil, humanity becomes culpable. Their disobedience results in the corruption of the state of grace in which God had originally created them. The divine-human relationship is henceforth shattered, $\sin$ becomes the defining trait of the human condition, and salvation its most important need.

The rest of the Old Testament's contribution to this story recounts God's efforts to restore the damaged relationship. Most of the account that follows focuses on Israel and God's repeated efforts to save his people from one problem or another. From a Christian perspective, however, the story of Israel does not represent God's total effort to offer salvation to humanity since it concerns only one people, Israel. For Christianity the climax of the history of God's saving activity comes with Jesus Christ, whose death and resurrection make salvation available to all humanity. In atoning for every sin, including Adam and Eve's original sin, it is only with Jesus that salvation becomes available to any and all human beings. The Old Testament needs a New in order that its project of salvation be complete.

Together, then, the two Testaments provide Christianity with a master-story. This grand récit, or "great code", as Northrop Frye calls it, governs the way the faithful understand history and the place of humanity in it. All of history, from its beginnings at the time of creation to its end as predicted in the book of Revelation, is understood as the drama of salvation, ${ }^{9}$ or what some Christian theologians call Heilsgeschichte. ${ }^{10}$ What the text asks of its readers is that they place their lives in the context of this drama. As Clark Pinnock recently put it,

We have access to the message of salvation through the Scriptures that God has given to bear witness to Christ, and these words become alive and effective in us through the work of the Spirit. Thus the Bible is an instrument or tool of the Spirit to teach and shape us. ${ }^{11}$

By placing the events of their lives within the context of the drama of salvation, 
Christians identify with the divine cause and especially those events in which God's saving activity is most obvious. As the recent statement on biblical authority issued by the United Church of Canada states:

The Bible is foundational because it recounts our foundational story. It provides a history of God's saving acts. It puts us in touch with our roots. The Bible tells our story as a community. 12

But the Christian experience of scripture is more than pedagogical. In some sense, for Christians the reading of the scriptures constitutes an encounter with God, indeed with Christ. One of the expressions that Christianity commonly uses to refer to its scriptures is "Word of God". In this context the phrase conveys the Christian conviction that the Bible is not an ordinary production of human literary activity but one of divine activity. ${ }^{13}$ In a sense real to Christians, the scriptures are understood to be authored by God. ${ }^{14}$ In reading them, the believer is thereby thought to come into contact with God.

What is particularly interesting about this expression is that it also refers to Jesus Christ. At least since the time of the writing of the Gospel of John, Christians have called Jesus the "Word of God". The opening of its oft-cited preface reads: "In the beginning was the Word, and the Word was with God, and the Word was God". As biblical historians have pointed out, the background of this expression is the Jewish notion, common in the first century, that God created the universe through the intermediary of a divine principle, usually described as Wisdom or Word. ${ }^{15}$ Thus John's gospel continues, "He was in the beginning with God; all things were made through him, and without him was not anything made that was made". But if both Christ and the Bible are the Word, to experience one is in some sense to experience the other. As Michael Edwards comments in his exploration of God's linguistic nature:
As the "word of God" - that is, the truth that he establishes, his utterances in the world, and also the scriptures - is related to the "Word of God" his Son, so contact with the language of the gospel can lead vertiginously to the Ground of language. ${ }^{16}$

The "Ground of language" for Edwards is deity itself. Edwards points to Gen.1 where God creates the universe through a series of speech acts. The logical implication of this account of creation, Edwards argues, is that language is prior to creation and thus an aspect of the divine. "God not only has language," Edwards writes, "he is language." 17 Referring to Christ as the Word is thereby an affirmation of the Christian conviction that he is "very God of very God". Referring to the Bible as the Word not only confirms its divine status, it affirms its ability to lead the faithful to an encounter of that other divine Word, which in some sense cannot be "other" at all.

Yet as Paul Ricoeur notes, in Christianity there is a sense in which it is illegitimate to speak of the Bible as sacred. It is not the scriptures themselves that are finally sacred, "but the one about which it is spoken". 18 The point can be made by comparing the Christian and Muslim attitudes to their respective scriptures. In Islam the Qur'an is understood to be an accurate transcription of God's actual words. Since those words were spoken in Arabic, it is only in Arabic that God's words can be fully experienced. To translate the Qur'an is to lose something of its meaning, and hence of the presence of God represented by the original. ${ }^{19}$

For Christianity there is no such problem. Christianity understands its scriptures as a human accounting of events in which God is perceived to be active. God may have inspired the writing of the scriptures, but it is only through human senses that the divine presence in events can be perceived, and it is only through human language that that perception can be expressed. Whether it be the King James's 
English, the Vulgate's Latin, or the Septuagint's Greek, the ability of the Bible to represent God to the believing community remains the same because it is independent of the specific words and language used.

The Bible, it would seem, has both divine and human elements. As Luis Alonso Schökel put it in explaining his choice for the title of his book: "That is why we have entitled our study, The Inspired Word, putting the accent on the concrete fact of the Bible as a reality both divine and human". ${ }^{20}$ Karl Barth's way of putting it is more provocative. Employing the terminology of the creeds, Barth describes the scriptures as fully human and fully divine. By putting it this way Barth not only acknowledges that the scriptures have both human and divine elements, but that the relationship between them is analogous to the relationship between the divine and human elements in Christ:

As the Word of God in the sign of this prophetic-apostolic word of man Holy Scripture is like the unity of God and man in Jesus Christ. It is neither divine only nor human only. Nor is it a mixture of the two nor a tertium quid between them. But in its own way and degree it is very God and very man, i.e., a witness of revelation which itself belongs to revelation, and historically a very human literary document. ${ }^{21}$

By applying christological language to the scriptures, Barth does not mean to identify the Bible with Christ. To confuse the two would be a form of idolatry or, as some might put it, "bibliolatry". Nonetheless, from the perspective of this formulation, an encounter with the scriptures constitutes a Christ-like experience in that by reading the Bible one encounters the perfect union of the divine and the human. The (re)establishment of that union in each person is, according to the Orthodox theologian Vladimir Lossky, the definition of salvation! ${ }^{22}$

In bringing this article to a close, I can think of no greater way to illustrate the saving power of the Christian scriptures than to cite Martin Luther. His quest for freedom from his personal sense of $\sin$ is proverbial. He received his salvation and comfort only upon reading Rom 1:17. Luther writes:

Here I felt that I was altogether born again and had entered paradise itself through open gates. There a totally other face of the entire Scripture showed itself to me. Thereupon I ran through the Scriptures from memory. I also found in other terms an analogy, as, the work of God, that is, what God does in us, the power of God, with which he makes us strong, the wisdom of God, with which he makes us wise, the strength of God, the salvation of God, the glory of God. ${ }^{23}$

\section{Notes}

1. For a convenient summary of the various formulations and the issues at stake in the debate see Alister McGrath, Christian Theology: An Introduction. Oxford: Blackwell, 1994, pp. 337-8.

2. For the first generation of Christians the story of Jesus was passed on orally. At that time the word "gospel" referred to the content of the preaching, based as it was on the conviction that Jesus was the Saviour. The term was applied to a book only after the first written account of Jesus appeared sometime after the 65 C.E.

3. There is a great deal of debate over the question of the genre of the gospels and of their relationship to the genre of biography. For a convenient survey of current opinion see W. S. Vorster, "Gospel Genre", Anchor Bible Dictionary. New York: Doubleday, 1992, 2.1077-9.

4. There are extra-canonical "gospels", the Gospel of Thomas being the most well known example, that have a different form and interest than the canonical four. However, since the groups that may have considered them scripture no longer exist, they are outside the purview of this article.

5. Of course there is a great deal of division amongst Christians on the precise meaning of "faith", and on the way faith should manifest itself in the believer. For a 
convenient summary of the issues between Catholic and Protestant forms of Christianity, see Alister McGrath, Christian Theology: An Introduction. Oxford: Blackwell, 1994, pp. 381-94.

6. See the discussion, for example, in J. L. Houlden, "Christian Interpretation of the Old Testament", A Dictionary of Biblical Interpretation. London/Philadelphia: SCM/Trinity, 1990, 108-12.

7. For a full discussion of the history of the idea of a messiah in Judaism, see the recent book by John J. Collins, The Scepter and the Star: The Messiahs of the Dead Sea Scrolls and Other Ancient Literature. New York: Doubleday, 1995.

8. See, for example, Clark Pinnock, The Scripture Principle. San Francisco: Harper \& Row, 1984, pp. 40-5.

9. Northrop Frye, The Great Code: The Bible and Literature. New York: Harcourt Brace Jovanovich, 1982, pp. 169-98.

10. On the variety of ways in which theologians use this term with reference to the Bible's view of history, see H. G. Reventlow, "Theology (Biblical), History of," Anchor Bible Dictionary. New York: Doubleday, 1992, 6.497-8.

11. Clark Pinnock, The Scripture Principle, p. 163.

12. The Authority and Interpretation of Scripture: A Statement of the United Church of Canada. Toronto: The United Church Publishing House, 1992, pp. 68-9.

13. This way of referring to the Bible is related to such terms as "inspired", "revelation", and "canon". While these terms are not synonymous, together they convey the sense that the scriptures are in some sense of God.
14. Although most Christians would agree with this statement, there is a great deal of debate over the mechanism and processes God used to author/inspire the biblical books. For a recent discussion of the various ways in which Christians understand the process, see Paul J. Achtemeier, The Inspiration of Scripture: Problems and Proposals. Philadelphia: Westminster, 1980.

15. The targums refer to this intermediary as the Memra, while Philo of Alexandria, like the Gospel of John, prefers the Greek, Logos.

16. Michael Edwards, Towards a Christian Poetics. Grand Rapids: Michigan, 1984, p.218.

17. Michael Edwards, Towards a Christian Poetics. p. 217.

18. Paul Ricoeur, "The 'Sacred' Text and the Community", Figuring the Sacred: Religion, Narrative, and Imagination. Minneapolis: Fortress, 1995, p. 68.

19. See, for example, W. C. Smith, What is Scripture? A Comparative Approach. Minneapolis: Fortress, 1993, p. 70.

20. L. Alonso Schökel, The Inspired Word: Scripture in the Light of Language and Literature. Montreal: Palm, 1965, p. 87.

21. Karl Barth, Church Dogmatics. Ed. G. W. Bromiley and T. F. Torrance; Edinburgh: T. \& T. Clark, 1956, I/2, 501:

22. Vladimir Lossky, Orthodox Theology: An Introduction. Crestwood: St. Vladimir's Seminary Press, 1978, pp. 119-37.

23. These remarks are contained in the preface to his Latin Works. I cite John Dillenberger's version in Martin Luther: Selections from His Writings. New York: Doubleday, $1962,11$. 